\title{
DISPARITAS PUTUSAN PRAPERADILAN DALAM PENETAPAN TERSANGKA KORUPSI OLEH KPK*
}

\author{
Alfitra \\ Fakultas Syariah dan Hukum UIN Jakarta \\ Jl. Ir. H. Juanda No. 95 Ciputat Tangsel \\ E-mail: alfitra@uinjkt.ac.id \\ DOI: $10.15408 /$ jch.v4i1.3201
}

\begin{abstract}
Pretrial is a new innovation in the Criminal Code. Pretrial intention is as a "translation" of the substance of habeas corpus rights. Pretrial become one of the court's discretion horizontally over the application of the force by the police, prosecutors, and the Commission, which include the validity of the arrest, detention, discontinuation of the investigation or the discontinuation of the prosecution, compensation / rehabilitation, and the validity of objects seized as a means of proof and determination of the suspect. With the institution of pretrial these "prisoners" or suspects who set olek Commission authorized by law to exercise supervision over the course of a forceful measures in the process of determination of the investigation after the enactment itself becomes suspect. The purpose of this monitoring, among other things kongkritisasi Aqusatoir concept of human rights and with the principles of presumption of innocence.
\end{abstract}

Keywords: Decision Pretrial, suspect corruption, KPK

\begin{abstract}
Abstrak: Praperadilan merupakan inovasi baru dalam KUHAP. Niat praperadilan adalah sebagai "terjemahan" habeas corpus yang merupakan substansi HAM. Praperadilan menjadi salah satu kewenangan pengadilan secara horizontal atas penerapan upaya paksa oleh polisi, jaksa, dan KPK, yang meliputi sah atau tidaknya penangkapan, penahanan, penghentian penyidikan atau penghentian penuntutan, ganti rugi/rehabilitasi, dan sah atau tidaknya benda yang disita sebagai alat pembuktian dan penetapan tersangka. Dengan adanya lembaga praperadilan ini "pesakitan" atau tersangka yang ditetapkan olek KPK diberi hak oleh Undang-Undang untuk melakukan pengawasan atas jalannya suatu upaya paksa dalam proses penetapan penyidikan setelah ditetapkannya dirinya menjadi tersangka. Tujuan pengawasan ini antara lain untuk kongkritisasi konsep HAM dengan prinsip Aqusatoir dan praduga tidak bersalah.
\end{abstract}

Kata Kunci: Putusan Praperadilan, Tersangka Korupsi, KPK

\footnotetext{
*Naskah diterima: 12 Februari 2016, direvisi: 23 Maret 2016, disetujui untuk terbit: 23 Mei
} 2016. 


\section{Alfitra}

\section{Pendahuluan}

Pasca putusan Mahkamah Konstitusi No. 21/PUU-XII/2014, yang dalam amar putusan mengatakan: "bukti permulaan yang cukup dan bukti yang cukup" sebagaimana ditentukan dalam Pasal 1 angka 14, Pasal 17 dan Pasal 21 ayat 1 Undang-Undang No. 8 Tahun 1981 tentang KUHAP (Lembaran Negara Republik Indonesia Tahun 1981 N0 76 Tambahan Lembaran Negara Republik Indonesia N0 3209) bertentangan UUD 1945 sepanjang tidak dimaknai bahwa "bukti permulaan", "bukti permulaan yang cukup" dan "bukti yang cukup" adalah minimal dua alat bukti yang dimuat dalam Pasal 184 KUHAP. ${ }^{1}$

Praperadilan diatur dalam Pasal tersendiri yaitu mengenai tuntutan ganti kerugian dan rehabilitasi sebagaimana diatur dalam Pasal 95 dan 97 KUHAP. Kewenangan secara spesifik praperadilan sesuai dengan Pasal 1 butir 10 dan Pasal 77 KUHAP adalah sebagai salah satu kewenangan Pengadilan secara horizontal atas penerapan upaya paksa oleh Polisi, Jaksa dan KPK yang meliputi sah atau tidaknya Penangkapan, Penahanan, Penghentian Penyidikan atau Penghentian Penuntutan, dan pasca putusan MK N0 21/PUU-XII/2014 ditambah Penetapan Tersangka. Berdasarkan Pasal 95 dan 97 KUHAP kewenangan praperadilan ditambah dengan kewenangan untuk memeriksa dan memutus ganti kerugian dan rehabilitasi.

Ganti kerugian dalam hal ini bukan hanya semata-mata mengenai akibat kesalahan upaya paksa, penyidikan maupun penuntutan, tetapi dapat juga ganti kerugian akibat adanya pemasukan rumah, penggeledahan dan penyitaan yang tidak sah secara hukum sesuai dengan penjelasan Pasal 95 ayat (1) KUHAP. Dalam Keputusan Menkeh RI No. M.01.PW.07.03 tahun 1982, praperadilan disebutkan dapat pula dilakukan atas tindakan kesalahan penyitaan yang tidak termasuk alat bukti, atau seseorang yang dikenakan tindakan lain tanpa alasan yang berdasarkan Undang-Undang, karena kekeliruan orang atau hukum yang diterapkan. Ganti kerugian diatur dalam Bab XII, Bagian Kesatu KUHAP. Perlu diperhatikan dalam Pasal 1 butir 22 menyatakan "Ganti kerugian adalah hak seseorang untuk mendapatkan pemenuhan atas tuntutannya yang berupa imbalan sejumlah uang karena ditangkap, ditahan, ataupun diadili tanpa alasan yang berdasarkan undangundang atau karena kekeliruan orangnya atau hukum yang diterapkan menurut cara yang diatur undang-undang ini.

Beranjak dari bunyi Pasal di atas, dapat ditangkap dengan jelas bahwa ganti rugi adalah alat pemenuhan untuk mengganti kerugian akibat hilangnya kenikmatan berupa kebebasan karena adanya upaya paksa yang tidak berdasar

\footnotetext{
${ }_{1}^{1}$ Putusan MK No. 21/PUU-XII/2014, h. 1
} 


\section{Disparitas Putusan Praperadilan Dalam Penetapan Tersangka Korupsi Oleh KPK}

hukum. Kiranya sangat tepat jika negara bertanggung jawab untuk membayar ganti rugi, sebab tindakan upaya paksa tentu dilakukan oleh aparat hukum yang merupakan bagian dari negara.

Bab X Bagian Kesatu mulai Pasal 79 sampai dengan Pasal 83 KUHAP diatur pihak-pihak yang dapat mengajukan praperadilan adalah; Pertama, tersangka atau keluarganya melalui kuasa hukum yang mengajukan gugatan praperadilan terhadap kepolisian atau kejaksaan di pengadilan atas dasar sah atau tidaknya penangkapan, penahanan, penyitaan dan penggeledahan; Kedua, Penuntut umum atau pihak ketiga yang berkepentingan atas dasar sah dan atau tidaknya penghentian penyidikan; Ketiga, Penyidik atau pihak ketiga yang berkepentingan atas dasar sah atau tidaknya penghentian penuntutan; Keempat, Tersangka atau pihak ketiga yang berkepentingan menuntut ganti rugi tentang sahnya penghentian penyidikan atau penuntutan (pasal 81 KUHAP); Kelima, Tersangka, ahli waris atau kuasanya tentang tuntutan ganti rugi atas alasan penangkapan atau penahanan yang tidak sah, penggeledahan atau penyitaan tanpa alasan yang sah atau karena kekeliruan orang atau hukum yang diterapkan, yang perkaranya tidak diajukan ke sidang pengadilan (Pasal 95 ayat (2) KUHAP). ${ }^{2}$

Ruang lingkup yang diatur KUHAP, dilihat dari sistem hukum Eropa Kontinental sesungguhnya lembaga praperadilan menyerupai fungsi examinating judge (Rechter Commissaries) yakni mengawasi apakah sah atau tidaknya suatu upaya paksa. Tetapi kewenangan Recter Commissaries lebih luas lagi karena dimungkinkan juga sebagai investigating judge seperti memanggil saksi-saksi dan ahli dalam melakukan penahanan dan mendatangi rumah saksi dan tersangka untuk pengecekan suatu kebenaran. ${ }^{3}$

Hakim sebagai manusia selalu dihadapkan pada pembuatan keputusan, baik dalam kehidupan sehari-hari maupun perannya dalam penegakan hukum di masyarakat. Dalam filosofinya hakim mengatakan "hakim lebih baik membebaskan 1000 orang yang bersalah ketimbang menghukum 1 orang yang tidak bersalah". Adagium semacam ini sudah banyak dilanggar/dilupai oleh hakim saat ini, sehingga yang cocok adalah "isi dulu rekening saya, baru saya menentukan hukuman terdakwa". Dalam kehidupan sehari-hari, manusia dihadapkan pada pengambilan keputusan berkaitan dengan diri sendiri untuk masalah karier, maupun jabatan yang diemban, serta dalam rumah tangga, dan sekolah. Pada saat memainkan peran sebagai manajer, dosen, psikologi, dan

2 M.Yahya Harahap, Pembahasan,Permasalahan dan Penerapan KUHAP, (Jakarta: Sinar Grafika 1998), h. 1-4.

${ }^{3}$ Luhut M.P. Pangaribuan, Hukum Acara Pidana, (Jakarta: Djembatan, 2008), h. 39. 


\section{Alfitra}

hakim, manusia harus mengambil keputusan yang berkaitan dengan orang lain. Manusia sebagai dosen dihadapkan pada pengambilan keputusan apakah seorang mahasiswa layak untuk lulus atau tidak, ataukah seorang mahasiswa layak mendapatkan nilai tinggi atau rendah. ${ }^{4}$

Apabila kesalahan manusia dalam pengambilan keputusan akan memberikan dampak negatif. Keputusan kecil yang salah akan berdampak kecil dan keputusan besar yang salah akan berdampak besar pula. Dalam upaya menghindari timbulnya kesalahan pengambilan keputusan, maka banyak kajian ilmu pengetahuan yang membahas pengambilan keputusan, salah satunya adalah dalam ilmu Psikologi.

Seorang hakim sebagai pengambil keputusan pada peradilan juga dihadapkan pada resiko yang sama, kesalahan pengambilan keputusan akan memberikan dampak yang besar pada terdakwa. Terdakwa yang sebenarnya tidak bersalah dapat menjalani hukuman atau terdakwa yang bersalah dapat dibebaskan, jika terjadi kesalahan pengambilan keputusan pada hakim. ${ }^{5}$ Mengajukan satu kesulitan dalam mengkaji keputusan hakim, yaitu tidak diketahuinya keputusan yang benar dan salah, sehingga hanya Tuhan yang mengetahui apakah suatu keputusan perkara pidana atau perdata adalah benar atau salah. Salah satu permasalahan yang dihadapi oleh hakim dalam pengambilan keputusan di persidangan adalah disparitas pemidanaan. Ada tiga macam bentuk putusan hakim dalam perkara pidana seperti apa yang diatur dalam KUHAP Pasal 191 (1) putusan bebas (2) putusan lepas dan 193 (1) putusan pemidanaan. ${ }^{6}$

Setiap disparitas pemidanaan diartikan sebagai penerapan pidana yang tidak sama terhadap tidak pidana yang sama. ${ }^{7}$ Atau tindak pidana yang sifatnya berbahaya dan dapat diperbandingkan. Jackson mengatakan disparitas pidana dapat juga terjadi pada pemidanaan yang berbeda terhadap dua atau lebih terdakwa yang melakukan bersama suatu delik tanpa suatu alasan yang jelas. ${ }^{8}$

Setiap disparitas menerima atau menolak suatu praperadilan yang diajukan oleh pemohon atau kuasanya, yang seharusnya tidak terjadi dengan mengumpulkan pemidanaan dalam perkara di tingkat pengadilan pertama

${ }^{4}$ Lestari, W Otorialisme dan Keputusan besarnya Hukuman, (Yogyakarta: Fakultas Psikologi UGM, 1999), h. 17.

${ }^{5}$ Sabini, J, Social Psikology New York, (Noerton Company, 1999), h. 13.

${ }^{6}$ Andi Hamzah, KUHP dan KUHAP Pasal 191(1, 2) dan 193 (1).

7 Poernomo, Barda Nawawi, Proses Pengambilan Keputusan dalam Perkara Pidana di Pengadilan, (Yogyakarta: Program Pasca Sarjana UGM, 2002), h. 35-37.

${ }^{8}$ Muladi dan Barda Nawawi, Teori-teori kebijakan Pidana, (Bandung: Alumni 2001), h. 40. 


\section{Disparitas Putusan Praperadilan Dalam Penetapan Tersangka Korupsi Oleh KPK}

terhadap penetapan seseorang menjadi tersangka oleh KPK atau oleh Polisi, Kejaksaan dalam tindak pidana korupsi dan tindak pidana umum (terjadi disparitas) antara enam bulan dalam tahun 2015, banyaknya penolakan praperadilan yang diajukan oleh tersangka atau penasehat hukumnya (terjadi disparitas). Disparitas dapat terjadi karena tidak ada standar profesi hakim dalam membuat keputusan secara otoriter. Hakim dalam memutuskan perkara praperadilan dalam Kitab Undang-undang Hukum Acara Pidana (KUHAP) hakim mempunyai kebebasan dalam mempertimbangkan fakta-fakta suatu perkara. Menyikapi hal demikian dapat disimpulkan bahwa pada kenyataannya masih terdapat disparitas tidak diterimanya praperadilan yang diajukan oleh pemohon, dalam hal ini apakah perlu dibuat patokan standar dapat diterima atau ditolaknya suatu perkara praperadilan, yaitu patokan diterima sebagian atau ditolak semuanya. Penentuan patokan disertai dengan pertimbangan-pertimbangan yang matang melalui musyawarah Hakim tunggal dengan ketua pengadilan setempat untuk menentukan besarnya patokan standar penolakan.

\section{Tujuan Praperadilan}

Praperadilan merupakan barang baru dalam kehidupan penegakan hukum di Indonesia. Setiap hal yang baru, mempunyai misi dan motivasi tertentu. Pasti ada yang dituju dan yang hendak dicapai. Tidak ada sesuatu yang diciptakan tanpa didorong oleh maksud dan tujuan. Demikian pula halnya dengan pelembagaan praperadilan, ada maksud dan tujuan yang hendak ditegakkan dan dilindungi, yakni untuk tegaknya hukum, dan perlindungan terhadap HAM tersangka dalam tingkat pemeriksaan penyidikan, penuntutan serta penetapan status tersangka.

Setiap upaya paksa yang dilakukan oleh pejabat Polisi, Kejaksaan dan KPK terhadap tersangka, pada hakikatnya merupakan perlakuan yang bersifat:

a. Tindakan paksa yang dibenarkan undang-undang demi kepentingan pemeriksaan tindak pidana yang disangkakan kepada tersangka.

b. Sebagai tindakan paksa yang dibenarkan oleh hukum dan undangundang, setiap tindakan paksa yang sendirinya merupakan perampasan kemerdekaan dan kebebasan serta pembatasan terhadap hak asasi tersangka.

Karena tindakan upaya paksa yang dikenakan instansi penegak hukum merupakan pengurangan dan pembatasan kemerdekaan dan HAM tersangka, tindakan itu harus dilakukan pertanggungjawaban menurut ketentuan hukum 


\section{Alfitra}

dan undang-undang yang berlaku (due process of law). ${ }^{9}$ Tindakan upaya paksa yang dilakukan bertentangan dengan hukum dan Undang-Undang yang berlaku dan merupakan pemerkosaan terhadap HAM tersangka. Karenanya, bagaimana mengawasi dan menguji tindakan paksa yang dianggap bertentangan dengan hukum. Untuk itu perlu diadakan suatu lembaga yang diberi wewenang untuk menentukan sah atau tidaknya tindakan paksa yang dilakukan penyidik, penuntut umum dan KPK yang dilimpahkan kewenangannya dalam hal ini kepada praperadilan.

Idealnya seorang hakim memiliki standar profesi dalam mengambil keputusan yang jeli sesuai dengan hati nurani. ${ }^{10}$ Disparitas dalam mengambil keputusan masih juga terjadi karena musyawarah penentuan standar diterima atau ditolaknya oleh hakim Pengadilan Negeri tidak berjalan dengan baik. Hal itu terbukti dari hasil penelitian yang menemukan bahwa dengan menggunakan 10 perkara praperadilan yang diajukan oleh para pemohon atau kuasa hukumnya yang ditetapkan tersangka, oleh KPK di pengadilan Jakarta Selatan pada tahun 2015.

\section{Perkara Praperadilan yang Masuk ke Pengadilan Jakarta Selatan (Tahun} 2015)

\begin{tabular}{|c|c|c|c|}
\hline & NOMOR PERKARA & $\begin{array}{l}\text { ALASAN } \\
\text { PERMOHON } \\
\text { AN }\end{array}$ & PUTUSAN \\
\hline 1 & $\begin{array}{l}\text { 119/Pid.Prap/2015/PN } \\
\text { Jkt-Sel } \\
\text { R. J.LINO Melawan } \\
\text { KPK }\end{array}$ & $\begin{array}{l}\text { PENETAPAN } \\
\text { TERSANGKA }\end{array}$ & $\begin{array}{l}\text { Menyatakan permohonan Pemohon dalam } \\
\text { Permohonan praperadilan tidak diterima untuk } \\
\text { seluruhnya. }\end{array}$ \\
\hline 2 & $\begin{array}{l}\text { 69/Pid.Prap/2015/ } \\
\text { PN.Jkt.Sel } \\
\text { Drs. RUSLI SIBUA, } \\
\text { M.Si Melawan KPK }\end{array}$ & $\begin{array}{l}\text { PENETAPAN } \\
\text { TERSANGKA }\end{array}$ & $\begin{array}{l}\text { Menyatakan permohonan Praperadilan Pemohon } \\
\text { gugur. }\end{array}$ \\
\hline 3 & $\begin{array}{l}\text { 16/Pid.Prap/2015/PN. } \\
\text { Jkt.Sel. } \\
\text { Drs. Ir. H. SUTAN } \\
\text { BHATOEGANA, MM } \\
\text { Melawan KPK }\end{array}$ & $\begin{array}{l}\text { PENETAPAN } \\
\text { TERSANGKA }\end{array}$ & $\begin{array}{l}\text { Menyatakan permohonan Praperadilan Pemohon } \\
\text { (Drs.Ir.H. Sutan Bhatoegana,MM) gugur; }\end{array}$ \\
\hline 4 & $\begin{array}{l}\text { 72/Pid.Prap/2015/PN. } \\
\text { Jkt.Sel }\end{array}$ & $\begin{array}{l}\text { PENETAPAN } \\
\text { TERSANGKA }\end{array}$ & $\begin{array}{l}\text { Menyatakan permohonan Praperadilan Pemohon } \\
\text { gugur }\end{array}$ \\
\hline
\end{tabular}

9 Karnasudirdja, Beberapa Pedoman Pemidanaan dan Pengamatan Pidana, (Jakarta: Mahkamah Agung 2002), h. 97.

${ }^{10}$ M. Yahya Harahap, Suatu Tinjauan Mengenai Pemidanaan, makalah disampaikan calon Hakim oleh Makamah Agung dan Depertemen Kehakiman di Jakarta, 1997. 


\begin{tabular}{|c|c|c|c|}
\hline & $\begin{array}{l}\text { Prof. Dr. Otto Cirnelis } \\
\text { Kaligis Melawan KPK } \\
\text { (OC. Kaligis } \\
\text { melakukan } \\
\text { permohonan Prap lagi } \\
\text { dengan nomor } \\
\text { 79/Pid.Prap/2015/PN. } \\
\text { Jkt.Sel. tapi dicabut } \\
\text { tanggal } 4 \text { September } \\
\text { 2015) }\end{array}$ & & \\
\hline 5 & $\begin{array}{lr}\text { 90/Pid.Prap/2015/PN. } \\
\text { Jkt.Sel } & \\
\text { Ir. } & \text { Budiantoro } \\
\text { Syahlani } & \text { Melawan } \\
\text { KPK } & \\
\end{array}$ & $\begin{array}{l}\text { PENETAPAN } \\
\text { TERSANGKA }\end{array}$ & Menolak permohonan pemohon untuk seluruhnya \\
\hline 6 & $\begin{array}{l}\text { 58/Pid/Prap/2015/PN. } \\
\text { Jkt.Sel NG HAKER } \\
\text { LARSON } \\
\text { MELAWAN } \\
\text { 1). Pemerintah } \\
\text { Republik Indonesia cq } \\
\text { Kepala Kepolisian RI } \\
\text { cq Kapolda Metro } \\
\text { Jaya } \\
\text { 2). Pemerintah } \\
\text { Republik Indonesia cq } \\
\text { Kepala Kejaksaan } \\
\text { Agung RI cq Kepala } \\
\text { Kejaksaan Tinggi DKI } \\
\text { Jakarta }\end{array}$ & $\begin{array}{l}\text { PENETAPAN } \\
\text { TERSANGKA }\end{array}$ & $\begin{array}{l}\text { 1. Mengabulkan permohonan dari pemohon } \\
\text { Praperadilan untuk sebagian; } \\
\text { 2. Menyatakan tindakan Termohon Praperadilan I } \\
\text { yang menetapkan pemohon Praperadilan } \\
\text { sebagai tersangka berdasarkan laporan Polisi } \\
\text { Nomor LP/1292/IV/PMJ/Ditreskri, Tanggal } 10 \\
\text { April } 2011 \text { adalah tidak sah; } \\
\text { 3. Memerintahkan Termohon Praperadilan I Untuk } \\
\text { menghentikan penyidikan terhadap diri } \\
\text { Pemohon Praperadilan; }\end{array}$ \\
\hline 7 & $\begin{array}{l}\text { 04/Pid.Prap/2015/PN. } \\
\text { Jkt.Sel. Komisaris } \\
\text { Jenderal Polisi Drs. } \\
\text { BUDI GUNAWAN, } \\
\text { SH., Msi. Melawan } \\
\text { KPK }\end{array}$ & $\begin{array}{l}\text { PENETAPAN } \\
\text { TERSANGKA }\end{array}$ & $\begin{array}{l}\text { DALAM POKOK PERKARA: } \\
\text { 1. Mengabulkan Permohonan } \\
\text { Praperadilan untuk sebagian; } \\
\text { 2. Menyatakan Surat Perintah Penyidikan Nomor: } \\
\text { Sprin.Dik-03/01/01/2015 tanggal } 12 \text { Januari } \\
2015 \text { yang menetapkan Pemohon sebagai } \\
\text { Tersangka oleh Termohon terkait peristiwa } \\
\text { pidana sebagaimana dimaksud dalam Pasal } 12 \\
\text { huruf a atau b, Pasal } 5 \text { ayat (2), Pasal } 11 \text { atau } \\
12 \text { B Undang-Undang Nomor } 31 \text { Tahun } 1999 \\
\text { tentang Pemberantasan Tindak Pidana Korupsi } \\
\text { jo. Undang-Undang Nomor } 20 \text { Tahun } 2001 \\
\text { tentang Perubahan atas Undang-undang } \\
\text { Nomor } 31 \text { Tahun } 1999 \text { tentang Pemberantasan } \\
\text { Tindak Pidana Korupsi jo. Pasal } 55 \text { ayat (1) ke- } \\
1 \text { KUHP adalah tidak sah dan tidak berdasar } \\
\text { atas hukum, dan oleh karenanya Penetapan } \\
\text { aquo tidak mempunyai kekuatan mengikat; }\end{array}$ \\
\hline
\end{tabular}




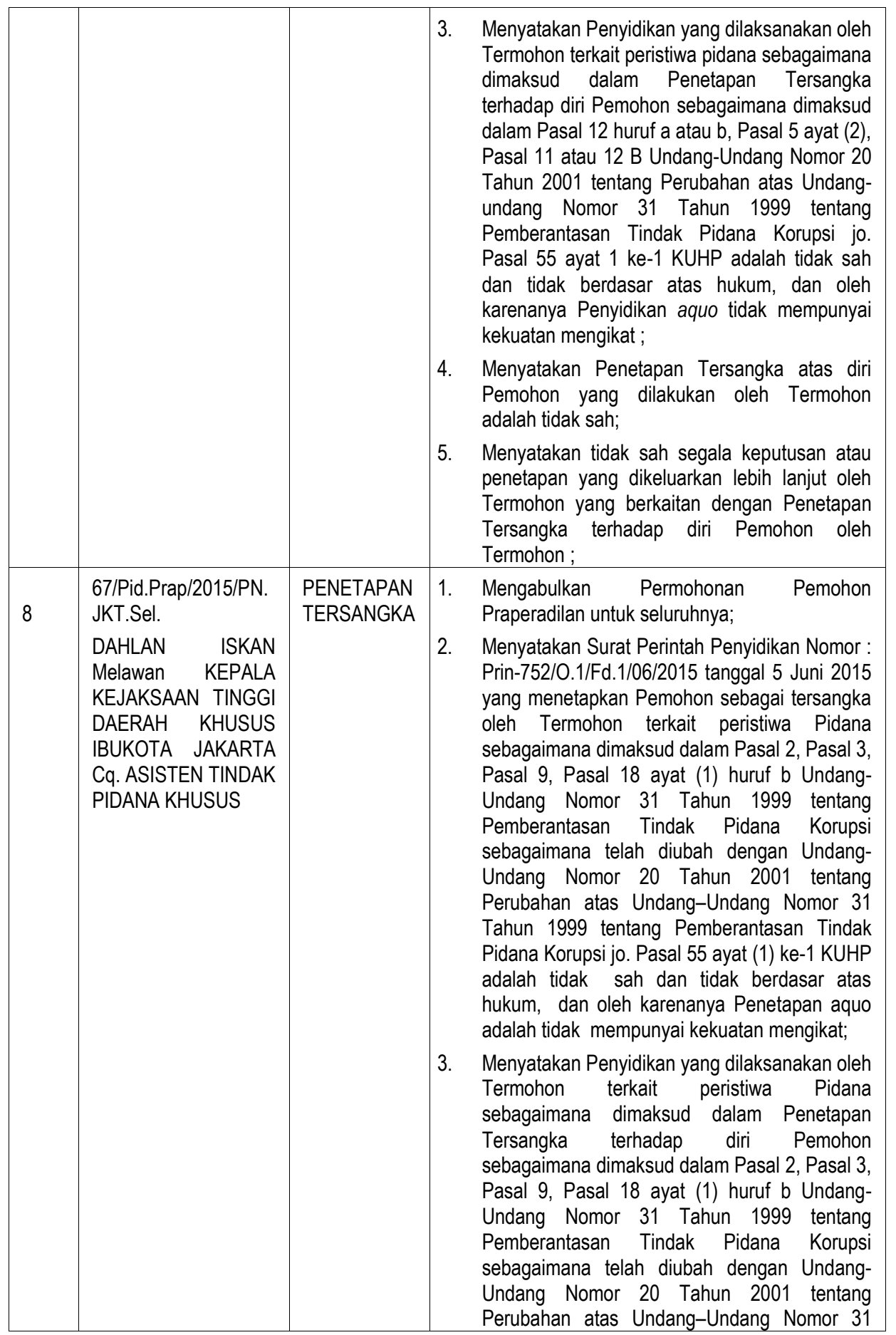




\begin{tabular}{|c|c|c|c|}
\hline & & & $\begin{array}{l}\text { Tahun } 1999 \text { tentang Pemberantasan Tindak } \\
\text { Pidana Korupsi jo. Pasal } 55 \text { ayat (1) ke-1 KUHP } \\
\text { adalah tidak sah dan tidak berdasar hukum, dan } \\
\text { oleh karenanya Penyidikan aquo tidak } \\
\text { mempunyai kekuatan hukum mengikat; } \\
\text { 4. Menyatakan Penetapan Tersangka atas diri } \\
\text { Pemohon yang dilakukan oleh Termohon } \\
\text { adalah tidak sah; } \\
\text { 5. Menyatakan tidak sah segala keputusan atau } \\
\text { penetapan yang dikeluarkan lebih lanjut oleh } \\
\text { Termohon yang berkaitan dengan Penetapan } \\
\text { Tersangka terhadap diri Pemohon oleh } \\
\text { Termohon; }\end{array}$ \\
\hline 9 & $\begin{array}{lc}\text { 55/Pid.Prap/ } & 2015 \\
\text { /PN.Jkt.Sel } & \\
\text { Dr. H. ILHAM } & \text { ARIEF } \\
\text { SIRAJUDIN, } & \text { MM. } \\
\text { Melawan KPK } & \\
\end{array}$ & $\begin{array}{l}\text { PENETAPAN } \\
\text { TERSANGKA }\end{array}$ & Menolak Permohonan Pemohon untuk seluruhnya \\
\hline 10 & $\begin{array}{l}\text { 36/Pid.Prap/2015/PN. } \\
\text { JKT.Sel. } \\
\text { HADI POERNOMO } \\
\text { Melawan KPK }\end{array}$ & $\begin{array}{l}\text { PENETAPAN } \\
\text { TERSANGKA }\end{array}$ & $\begin{array}{l}\text { 1. Mengabulkan permohonan Pra Peradilan } \\
\text { 2. } \\
\text { Pemohon untuk sebagian; } \\
\text { Termatakan Penyidikan yang dilakukan oleh } \\
\text { sebagaimana dinyatakan dalam penetapan } \\
\text { sebagai Tersangka terhadap diri Pemohon yang } \\
\text { diduga melanggar Pasal } 2 \text { ayat (1) atau Pasal } 3 \\
\text { Undang-Undang No.31 Tahun 1999 Tentang } \\
\text { Pemberantasan Tindak Pidana Korupsi Jo. } \\
\text { Undang-Undang No. } 20 \text { Tahun } 2001 \text { tentang } \\
\text { perubahan atas Undang-Undang No. } 31 \text { Tahun } \\
\text { 1999 JIS Pasal } 55 \text { ayat (1) ke } 1 \text { KUHP adalah } \\
\text { tidak sah oleh karenanya penyidikan aquo tidak } \\
\text { mempunyai kekuatan hukum mengikat dan oleh } \\
\text { karena itu di perintahkan kepada Termohon } \\
\text { untuk menghentikan penyidikan berdasarkan } \\
\text { Surat Perintah Penyidikan, No. Sprin DIK- } \\
\text { 17/01/04/2014 tanggal } 21 \text { April 2014; } \\
\text { Menyatakan menurut hukum tindakan } \\
\text { Termohon menetapkan Pemohon sebagai } \\
\text { Tersangka yang melanggar Pasal } 2 \text { ayat (1) } \\
\text { atau Pasal } 3 \text { Undang-Undang No. } 31 \text { Tahun } \\
\text { 1999 Tentang Pemberantasan Tindak Pidana } \\
\text { Korupsi Jo. Undang-Undang No. 20 Tahun } \\
\text { 2001 Tentang Perubahan atas Undang-Undang } \\
\text { No. 31 Tahun 1999 JIS Pasal } 55 \text { ayat (1) ke } 1 \\
\text { KUHP berdasarkan Surat Perintah Penyidikan } \\
\text { No. Sprin Dik-17/01/04/2014 adalah tidak sah } \\
\text { dan tidak berdasarkan atas hukum dan oleh } \\
\text { karenanya Penetapan Tersangka aquo tidak } \\
\text { mempunyai kekuatan hukum mengikat. }\end{array}$ \\
\hline
\end{tabular}




\begin{tabular}{|l|l|l|}
\hline $4 . \begin{array}{l}\text { Menyatakan Penyitaan yang dilakukan } \\
\text { Termohon terhadap barang milik Pemohon } \\
\text { adalah tidak sah dan oleh karenanya tidak } \\
\text { mempunyai kekuatan hukum mengikat; }\end{array}$ \\
$5 . \begin{array}{l}\text { Menyatakan tidak sah segala keputusan atau } \\
\text { penetapan yang dikeluarkan lebih lanjut oleh } \\
\text { Termohon yang berkenaan dengan penetapan } \\
\text { Tersangka atas diri Pemohon oleh Termohon; }\end{array}$ \\
\hline
\end{tabular}

Salah satu faktor penyebab disparitas penolakan hakim adalah adanya perbedaan aliran hukum pidana yang dianut oleh hakim. Macam-macam filosofi dan tujuan dari hukuman dapat dijelaskan dari tiga macam aliran hukum pidana. ${ }^{11}$

Pertama; Aliran Klasik. Salah satu tokoh aliran klasik, yaitu Cesare mengajarkan ajaran yang memuja pidana sebagai sarana ampuh untuk mengatasi kejahatan. Pidana ditentukan secara pasti oleh pembuat undangundang dan sama sekali tidak diizinkan perbedaan pemidanaan.

Kedua; Aliran Modern. Lomborso merupakan salah satu pelopor aliran ini yang mengajarkan pemberian hukuman yang bergantung dari kasus kriminal, artinya setiap pelaku pidana memiliki kebutuhan yang berbeda-beda. Adalah suatu kebodohan jika menerapkan pidana yang sama kepada semua orang yang melakukan tindak pidana tertentu. Pada tahun-tahun setelah perang dunia II, aliran modern berkembang menjadi aliran yang memusatkan tujuannya pada pencegahan kejahatan dari pembinaan para pelaku tindak pidana.

Ketiga; Aliran Neo Klasik. Aliran ini berkembang selama abad ke-19 dan mempunyai dasar yang sama dengan aliran klasik, tetapi dilakukan sedikit modifikasi. Modifikasi yang dilakukan antara lain; diterimanya asumsi bahwa penyebab kejahatan dapat karena patologi, ketidakmampuan, penyakit jiwa, diterimanya keadaan-keadaan yang dapat meringankan hukuman baik fisik, lingkungan ataupun mental, juga dilakukannya modifikasi dengan pertanggungjawaban pidana sebagian dalam keadaan khusus karena gila, di bawah umur atau keadaan lain yang dapat mempengaruhi pengetahuan dan niat seseorang pada saat terjadi kejahatan diperkenankannya saksi ahli untuk menentukan derajat pertanggungjawaban. Aliran Neoklasik tersebut sebenarnya berawal dari aliran klasik yang dalam perkembangannya kemudian dipengaruhi aliran modern.

${ }^{11}$ Rahayu, Putusan Hakim dalam Perkara Pidana Suatu Kajian Psikologis, (Yogyakarta: Bulletin Psikologi UGM, 2005), h. 1-10. 


\section{Disparitas Putusan Praperadilan Dalam Penetapan Tersangka Korupsi Oleh KPK}

Dari perbandingan karakteristik antar aliran-aliran dalam hukum pidana, dapat dikatakan bahwa persoalan disparitas pidana tidak akan muncul jika dianut sistem klasik yang dalam pemidanaannya menganut hukum yang pasti. Sedangkan disparitas pidana merupakan sesuatu yang dibenarkan menurut aliran modern. Hal itu sesuai prinsip Lombroso yang mengatakan bahwa setiap pelaku kriminal memiliki kebutuhan yang berbeda-beda. Jadi tampaknya yang dibutuhkan adalah suatu prinsip yang sama sebagai sarana untuk mencapai pertimbangan yang setara saat hakim menjatuhkan pidana. ${ }^{12}$

Hakim di Indonesia mempunyai kebebasan dalam memilih jenis pidana. Selain itu, hakim juga memiliki kebebasan untuk menentukan berat ringannya pemidanaan karena yang ditentukan oleh pembuat undang-undang adalah batas maksimal dan minimal. Pasal 12 ayat 2 Kitab Undang-undang Hukum Pidana menyatakan pidana penjara yang paling pendek adalah satu hari dan paling lama adalah 15 tahun berturut-turut, dan kalau terjadi pemberatan yang diatur dalam Pasal 52, 63, 486, 487 dan 488 KUHP 20 tahun atau seumur hidup. Di samping minimal umum dan maksimal umum, pada setiap Pasal tindak pidana dicantumkan maksimal khususnya (untuk masingmasing tindak pidana). Oleh karena itu, disparitas pemidanaan sangat dimungkinkan terjadi di Indonesia, bahkan dirasakan sebagai suatu permasalahan hukum yang bisa saja terjadi dalam tindak pidana yang sama oleh pengadilan yang sama dan diputus oleh hakim yang sama pula. ${ }^{13}$

Disparitas praperadilan dalam penetapan tersangka di tingkat penyidikan dalam kasus tindak pidana korupsi oleh KPK mengakibatkan munculnya perasaan ketidakadilan, baik oleh tersangka maupun masyarakat secara luas, sehingga tersangka ataupun masyarakat menjadi tidak menghargai hukum. Padahal penghargaan terhadap hukum merupakan salah satu target tujuan hukum yang dicapai. Hal ini juga merupakan salah satu indikator dan manifestasi dari kegagalan sistem untuk mencapai persamaan keadilan di negara hukum dan sekaligus akan melemahkan kepercayaan masyarakat terhadap sistem penyelenggaraan hukum pidana. ${ }^{14}$

Poernomo mengatakan bahwa disparitas terhadap praperadilan pidana yang bermasalah adalah pemidanaan yang berbeda dalam perkara yang sama pada situasi dan kondisi yang sama. Sedangkan disparitas yang tidak bermasalah jika keputusan hakim berbeda pada perkara yang sama namun

12 Poernomo. B, Manfaat Telaah Ilmu Hukum Pidana dalam Membangun Model Penegakan Hukum di Indonesia, (Yogyakarta: Fakultas Hukum UGM 2001), h. 28-20.

13 Susilowati, Keyakinan Hakim dan Alat Bukti dalam Putusan Hakim Pidana, (Surabaya: Buletin Ilmiah Universitas Surabaya, 2003), h. 49-57

14 Barda Nawawi, Teori-teori Kebijakan Pidan, (Bandung: Alumni, 2001), h.55 


\section{Alfitra}

situasi dan kondisinya berbeda. Lebih jauh Poernomo mencontohkan bahwa disparitas pemidanaan yang diperbolehkan adalah keputusan hakim tahun 1990an dan tahun 2000an tentang perkosaan akan berbeda karena hakim akan mempertimbangkan situasi dan kondisi yang berbeda. Korban tahun 1990 yang berpakaian tertutup akan berbeda dengan korban tahun 2000 yang berbusana menantang atau terbuka, sehingga hakim akan memberi hukuman ringan pada terdakwa kasus perkosaan tahun 1990 dibanding dengan tahun 2000an. Pertimbangan hakim akan berkembang seiring dengan perkembangan waktu.

Muladi dan Nawawi berpendapat tidak memberikan batasan disparitas pemidanaan yang diperbolehkan atau tidak, tetapi dikatakan bahwa disparitas yang berdasarkan pembenaran yang masuk akal dapat diterima. ${ }^{15}$ Keseimbangan pemidanaan harus didasarkan pada pertimbangan yang serasi dengan keputusan-keputusan yang sudah ada. Selain serasi dengan keputusankeputusan hakim lain dalam perkara yang sejenis. Serasi dengan keadilan masyarakat, dan serasi pula dengan keadilan terpidana. Jadi tampaknya disparitas dalam penjatuhan pemidanaan diperbolehkan jika telah melalui pertimbangan yang tepat dan logis dan harus bersifat objektif. Dengan memberikan pertimbangan yang tepat adalah pertimbangan yang serasi dengan keputusan yang telah ada, serasi dengan keputusan hakim lain dalam perkara yang sejenis, sesuai dengan keadilan masyarakat, serasi dengan situasi kondisi, keadaan terdakwa, dan sesuai dengan perkembangan.

Salah satu penyebab terjadinya disparitas dalam menjatuhkan atau memberi pemidanaan dalam kasus perkara karena tidak sejenis/persis, dan karakteristik terdakwanya berbeda. ${ }^{16}$ Harahap menjelaskan bahwa faktor-faktor yang menentukan berat ringannya pemidanaan adalah keseriusan tidak pidana, berbahaya atau tidaknya terdakwa, umur terdakwa, keadaan keluarga, pekerjaan, perilaku selama persidangan, dan opini publik. Lebih lanjut Harahap menjelaskan bahwa faktor-faktor di atas tidak mutlak karena bergantung dari pandangan hakim itu sendiri.

Hal itu menunjukkan semakin besar kemungkinan terjadinya disparitas pemidanaan yang dilakukan secara eksperimen dengan menggunakan satu perkara yang sama terhadap kejahatan. Penetapan tersangka kepada seseorang yang diduga melakukan tindak pidana korupsi ditemukan penjatuhan putusan yang bervariasi (terjadi disparitas). Hal itu menunjukkan terdapat faktor-faktor lain yang menyebabkan terjadinya disparitas dapat diterimanya permohonan

${ }^{15}$ Karnasurdirdja, E.D, Beberapa Pedoman Pemidanaan dan Pengamatan Pidanana, (Jakarta: Mahkamah Agung, 2001), h. 17.

${ }^{16}$ Lestari.W. Otoritarialisme dan Keputusan Besarnya Hukuman, (Yogyakarta: Fakultas Psikologi UGM, 1999), h. 45. 


\section{Disparitas Putusan Praperadilan Dalam Penetapan Tersangka Korupsi Oleh KPK}

pemohon praperadilan dalam penetapan tersangka. Faktor-faktor itulah yang ingin dijelaskan oleh psikologi.

Dalam memutuskan suatu perkara, hakim seringkali dipengaruhi oleh faktor-faktor yang tidak disadarinya. Seperti contoh, di Amerika Serikat dan Perancis banyak terdakwa kulit hitam yang dihukum lebih berat dibandingkan terdakwa ras kulit putih. Sebenarnya tidak ada niatan hakim Amerika Serikat maupun Perancis untuk melakukan hal itu, tetapi prasangka sosial yang ada dalam dirinya menyebabkan ia memutuskan hukuman yang lebih berat kepada terdakwa kulit hitam.

Diamond menjelaskan terjadinya disparitas dalam penjatuhan hukuman atau pidana karena: a). Tidak konsistennya barang bukti dan alat bukti yang diajukan di persidangan yang disebabkan rendahnya kredibilitas saksi dan adanya perbedaan penilaian hakim terhadap bukti selama di persidangan berlangsung; b). Tidak adanya standar proses pembuatan putusan baik oleh hakim maupun dalam KUHAP. ${ }^{17}$

Para psikolog di Eropa mulai membuktikan banyak faktor psikologis yang mempengaruhi hakim dalam pengambilan keputusan dalam penjatuhan pidana kepada pelaku kejahatan. ${ }^{18}$ Dalam penelitian seperti itu berguna untuk membuka wawasan tentang faktor psikologis yang berpengaruh dalam pengambilan keputusan pemidanaan, sehingga dapat ditentukan faktor-faktor yang relevan untuk dipertimbangkan kesalahan yang dilakukan oleh terdakwa, dalam penjatuhan pidana dan faktor yang negatif (misal diskriminasi rasial) dapat diperkecil pengaruhnya.

\section{Penutup}

Pemeriksaan sidang praperadilan dilakukan dengan acara cepat, mulai dengan penunjukan hakim, penetapan hari sidang, pemanggilan para pihak. Pemeriksaan sidang praperadilan dilakukan dengan cara cepat selambatlambatnya dalam jangka 7 hari. Karena itu bentuk putusan praperadilan cukup sederhana tanpa mengurangi isi pertimbangan yang jelas berdasarkan hukum dan undang-undang. Berdasarkan Pasal 82 ayat 1 huruf c KUHAP proses pemeriksaan sidang praperadilan dengan acara cepat harus diterapkan secara konsisten dengan bentuk dan pembuatan putusan dalam acara pemeriksaan singkat dan acara pemeriksaan cepat. Artinya adalah di mana putusan yang dirangkai menjadi satu dengan berita acara. Dalam Pasal 83 ayat 3 huruf a dan

17 Atmasasmita, Bunga Rampai Hukum Acara Pidana, (Bandung: Bina Cipta, 1990), h. 51-53.

18 Scheer, C.J, and Hammonds,B.L, Psikology and The Law 2. (Wasinton: American Psichology Asscosionty, 2002), h. 33. 


\section{Alfitra}

Pasal 96 ayat 1 bentuk putusan praperadilan berupa "penetapan", lazimnya penetapan ini merupakan rangkaian berita acara dengan isi putusan itu sendiri, kelaziman ini juga dijumpai dalam putusan perdata. Putusan praperadilan juga bersifat deklaratoir yang berisi pernyataan tentang sah atau tidaknya penangkapan, penahanan, penggeledahan atau penyitaan dan penetapan status tersangka.

\section{Pustaka Acuan}

Atmasasmita, Romli. Bunga Rampai Hukum Acara Pidana, Bandung: Bina Cipta, 1990.

Barda Nawawi, Arif. Teori-Teori Kebijakan Pidana, Bandung: Alumni, 1999.

Hamzah, Andi. KUHP dan KUHAP.

Harahap, M. Yahya. Pembahasan, Permasalahan dan Penerapan KUHAP, Jakarta: Sinar Grafika, 1998.

Karnasudirdja. Beberapa Pedoman Pemidanaan dan Pengamatan Pidana, Jakarta: Makamah Agung, 2002.

Lestari.W. Otoritarialisme dan Keputusan Besarnya Hukuman, Yogyakarta: Fakultas Psikologi UGM 1999.

Muladi dan Barda Nawawi. Teori-Teori Kebijakan Pidana, Bandung: Alumni, 2001. Pangaribuan, Luhut M.P. Hukum Acara Pidana, Jakarta: Djembatan, 2008.

Poernomo. B. Manfaat Telaah Ilmu Hukum Pidana dalam Membangun Model Penegakan Hukum di Indonesia, Fakultas Hukum UGM 2001.

Poernomo dan Barda Nawawi. Proses Pengambilan Keputusan dalam Perkara Pidana di Pengadilan, Program Pasca Sarjana UGM, 2002.

Putusan MK. No. 21/PUU-XII/2014.

Rahayu. Putusan Hakim dalam Perkara Pidana suatu Kajian Psikologis. Buletin Psikologi UGM, Yogyakarta, 2005.

Rahayu, Yusti Probowwati. Dibalik Putusan Hakim, Surabaya: Srikandi 2005.

Sabini, J. Social Psichology New York, Noerton Company, 1999.

Scheer, C.J, DAN Hammonds, B.L, Psichology and The Law 2. Washington American Psichology Association, 2002.

Susilowati. Keyakinan Hkim dan Alat Bukti dalam Putusan Hakim Pidana, Buletin Ilmiah Universitas Surabaya. 2003. 